\title{
SPATIAL VARIABILITY IN THE POPULATION OF Isognomon bicolor (C.B. ADAMS, 1845) (MOLLUSCA, BIVALVIA) ON ROCKY SHORES IN ESPÍRITO SANTO, BRAZIL
}

Gabriela Carvalho Zamprogno ${ }^{1 *}$, Luiz Loureiro Fernandes ${ }^{2}$ and Flavio da Costa Fernandes ${ }^{3}$

${ }^{1}$ Universidade Federal do Espírito Santo - Programa de Pós Graduação em Ciências Biológicas (Av. Marechal Campos, 1468, 29040-090 Vitória, ES, Brasil)

${ }^{2}$ Universidade Federal do Espírito Santo - Departamento de Oceanografia e Ecologia (Av. Fernando Ferrari, 514, 29075-910 Vitória, ES, Brasil)

${ }^{3}$ Instituto de Estudos do Mar Almirante Paulo Moreira - IEAPM (Rua Kioto, 253, 28930-000, Arraial do Cabo, RJ, Brasil)

*gczamprogno@gmail.com

\section{A B S T R ACT}

This study aimed to compare the density of Isognomon bicolor on four rocky shores of the State of Espírito Santo, Brazil. Further, size and weight comparisons were undertaken for the flat and creviced surfaces. Quarterly samplings were taken in 2006 and 2007, by removing organisms from $10 \times 10 \mathrm{~cm}$ quadrants in the mid-intertidal zone, with five samples from flat surfaces and five from crevices. Although densities of I. bicolor were considered low as compared with those of other studies, this species is well established in the State. The most well-established population of $I$. bicolor was found in the rock crevices. The most important factor for the establishment of I. bicolor on rocky shores is substrate heterogeneity.

\section{RESUMO}

O objetivo deste estudo foi comparar a densidade de Isognomon bicolor em quatro costões rochosos no Espírito Santo, Brasil. Além disso, comparações do tamanho e do peso foram feitas para as superfícies lisas e com fendas. Coletas trimestrais foram realizadas entre 2006 e 2007, os organismos foram removidos utilizando um quadrado de $100 \mathrm{~cm}^{2}$ na faixa do médiolitoral, sendo cinco nas superfícies lisas e cinco nas fendas. As densidades de I. bicolor foram consideradas baixas em comparação com outros estudos, mas a espécie encontra-se bem estabelecida. Foi obtido um maior número de indivíduos nas fendas. $\mathrm{O}$ fator mais importante para o estabelecimento de I. bicolor nos costões rochosos estudados mostrou ser a heterogeneidade do substrato.

Descriptors: Rocky shores, Intertidal zone, Introduced species, Substrate heterogeneity, Isognomon bicolor, Espírito Santo.

Descritores: Costão rochoso, Zona entremarés, Espécies introduzidas, Heterogeneidade de substrato, Isognomon bicolor, Espírito Santo.

\section{INTRODUCTION}

Rocky shores are subject to a variety of stresses caused by human activity, including the introduction of species, whether intentional or accidental (CROWE et al., 2000). The introduction of marine organisms affects native species mainly due to the resulting competition for food and space (KADO, 2003). Some invasions may have significant economic impact as well as constituting serious risks to human health (RUIZ et al., 1997). However, in many cases, the introduction of exotic species has no dramatic influence on marine communities (CROWE et al., 2000).

The main vectors involved in the introduction of species into marine environments are ship ballast water, fouling and the importation of exotic species for aquaculture and the aquarium trade (AMARAL; JABLONSK, 2005).

Alterations in the structure of benthic communities brought about by the introduction of bivalves has been widely investigated (CARLTON, 1992). The recent invasion of the Brazilian coast by Isognomon bicolor may be the result of an unintentional introduction by fouling or ballast water. Native to the Caribbean, this species currently occurs on rocky shores along the Brazilian coast (DOMANESCHI; MARTINS, 2002; FERNANDES et al., 2004; MOYSÉS et al., 2007). However, the extent of the damage caused by their introduction is unknown (FERNANDES et al., 2004).

Many studies have investigated the role of topographical heterogeneity in the distribution of intertidal communities (ARCHAMBAULT; 
BOURGET, 1996; BLANCHARD; BOURGET, 1999; BARRETO, 1999; MENCONI et al., 1999; GUICHARD et al., 2001; UNDERWOOD, 2004; SKINNER; COUTINHO, 2005). The physical factors of the environment and, consequently, the structure of the local community, can change abruptly within a small space, if the complexity of the habitat is high (BENEDETTI-CECCHI; CINELLI, 1997). Complex surfaces can create a variety of niches which serve as a refuge for animals (KOSTYLEV et al., 2005).

This study aimed to compare the density of I. bicolor populations on four rocky shores, and to assess the influence of the number of crevices on their density. This study also aimed to evaluate the size and weight of I. bicolor populations on two types of rocky surface: flat and creviced.

\section{Material and Methods}

Study Area

This study was carried out in the coastal zone of the State of Espírito Santo, Southeastern Brazil, characterized by Crystalline Precambrian rocks in contact with Quaternary deposits (MARTIN et al., 1996).

The most frequent and intense winds are, respectively, those from the northeast and southeast, the former prevailing during the greater part of the year, the southeasterly winds being associated with the cold fronts that occur regularly in the State's coastal zone (ALBINO et al., 2001).

Samples were collected on four rocky shores (Fig. 1): Area $1\left(20^{\circ} 19^{\prime} 44^{\prime \prime} \mathrm{S}, 40^{\circ} 16^{\prime} 20^{\prime \prime} \mathrm{N}\right)$ on the
Costa beach, in the Santa Luzia Hills; Area 2 (20'19'59''S, 40 16 '24' $\mathrm{N}$ ) also on Costa beach, but at Sereia Point, located $0.4 \mathrm{~km}$ from area 1; Area 3 (20³8'06''S 40'25'28''N) on Setibão beach, located

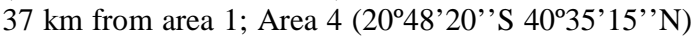
on Ubu beach, situated about $62 \mathrm{~km}$ from area 1 .

\section{Sampling Design}

Sampling was performed quarterly in each area (Fig. 1) between August 2006 and May 2007, during low tide.

Samples were taken in the mid-intertidal zone within a horizontal stretch of 18 meters on each rocky shore. All crevices (depressions in the rock with depth greater than $3 \mathrm{~cm}$ ) present in the area were counted and their length and depth measured.

On each rocky shore, within the range of the widest coverage of Isognomon bicolor, 5 quadrants $(10 \times 10 \mathrm{~cm})$ were sampled on two types of rock surfaces: flat, those without depressions, and creviced, with depressions of between 3 and $5 \mathrm{~cm}$ depth. The organisms were collected with a spatula. In the laboratory, all individuals of $I$. bicolor were weighed with a digital scale (precision of $0.01 \mathrm{~g}$ ) and their shell height measured, determined by the distance between two parallels: tangential hinge tooth and the ventral margin of the shell, in accordance with Domaneschi and Martins (2002), and the total length of the shell (greater extent) from the umbo, using callipers (precision of $0.05 \mathrm{~mm}$ ) (Fig. 2).

The sex of I. bicolor was defined by microscopic observation of the gonads (magnification $100 \mathrm{x})$.

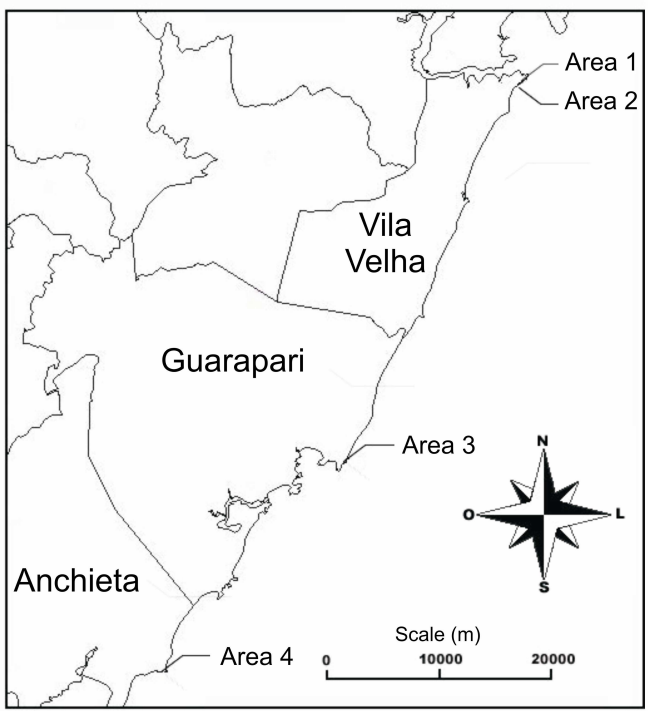

Fig. 1. Location of the study area. Areas 1 and 2: Costa beach; area 3: Setibão beach, and area 4: Ubu beach. 


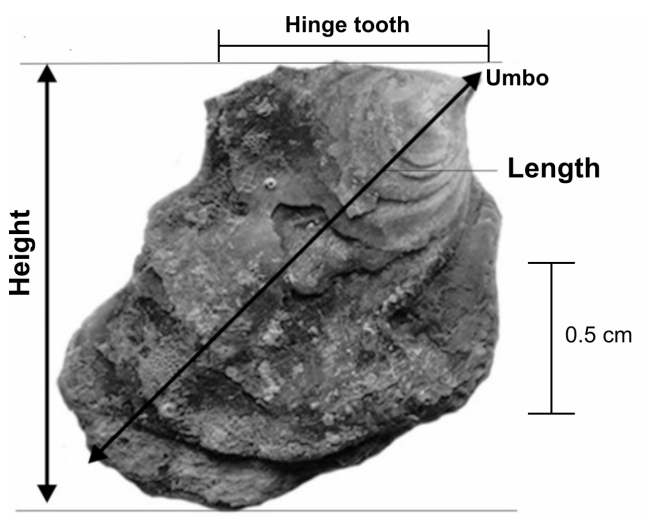

Fig. 2. External view of Isognomon bicolor indicating the two measurements.

\section{Data Analysis}

The sex ratio between the sampling areas was compared using the non-parametric Chi-square test (ZAR, 1996).

To calculate the population density, only individuals collected on the flat surfaces (without crevices) were considered, since it was not possible to estimate the area of the creviced surfaces due to their irregularity. One-factor analysis of variance (ANOVA) was performed to compare density values of I. bicolor among the sampling areas $(1,2,3$ and 4$)(\mathrm{N}=80)$. The two-factor ANOVA test was used to compare the length, height and weight of the shells by area of sampling and type of surface (flat or creviced) $(\mathrm{N}=$ 974). The Tukey test was carried out for multiple comparisons of the averages (ZAR, 1996). A Bonferroni test was used to measure the differences of the estimated marginal means as between the creviced and flat surfaces. Assumptions of normality and variance homogeneity where tested prior to all analyses by Kolmogorov-Smirnof's and Levene's tests, respectively. The hypothesis of normality and homogeneity was accepted only for the density, transformed in a $\ln (X+1)$. For length, height and weight, parametric analysis with the unprocessed data was carried out, because of the symmetry of the data. Also, in accordance with Xavier (2008), the data were tested again with Kruskal-Wallis and ANOVA and always led to the same conclusion.

Spearman's non-parametric test was used to verify possible correlations between the average density in each area and season $(\mathrm{N}=16)$ and the number of crevices.

For the analysis of size frequency distribution (length), individuals were classified according to the formula proposed by Sturges, described by Massad et al. (2004). The determination of classes was obtained by the equation $\mathrm{N}=1+3.322$ $\log (\mathrm{n})$, where $\mathbf{N}$ is the number of classes and $\mathbf{n}$ is the total number of individuals. The size of each interval (w) was obtained through the formula $\mathrm{w}=\mathrm{R} / \mathrm{N}$, where $\mathbf{R}$ is the difference between the highest and lowest value.

For all tests, $\alpha$ was equal to 0.05 .

\section{RESUlts}

\section{Characteristics of the Crevices}

On the Costa beach (area 2) the recorded crevices were larger, deeper and more numerous, while in area 1, the values were lower (Fig. 3).

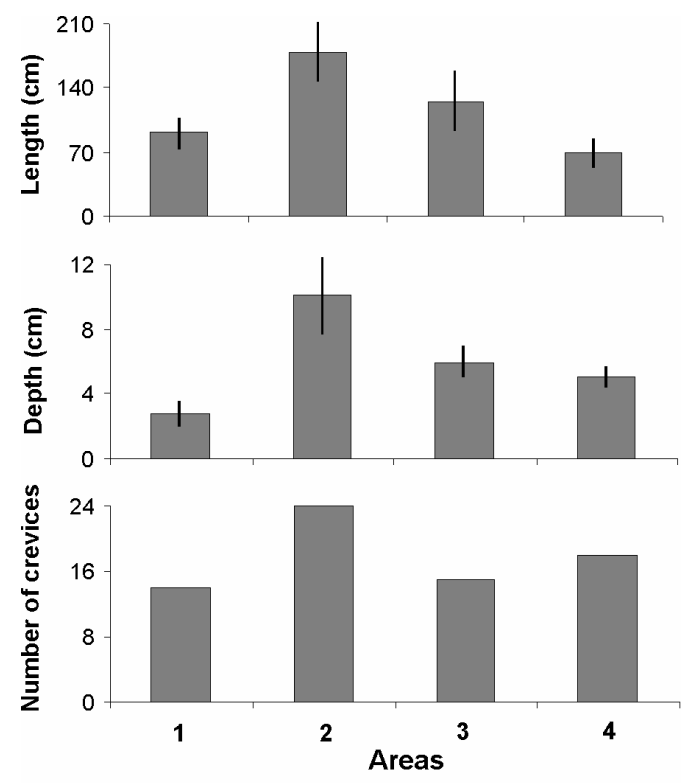

Fig. 3. Average values ( \pm standard error) of length and depth $(\mathrm{cm})$ of crevices and their number recorded for areas 1 and 2 (Costa), area 3 (Setibão) and area 4 (Ubu).

\section{Sex Ratio}

The proportion of females varied from $48 \%$ in area 1 to $55 \%$ in area 2 (Fig. 4). The Chi-squared test showed no significant differences among areas.

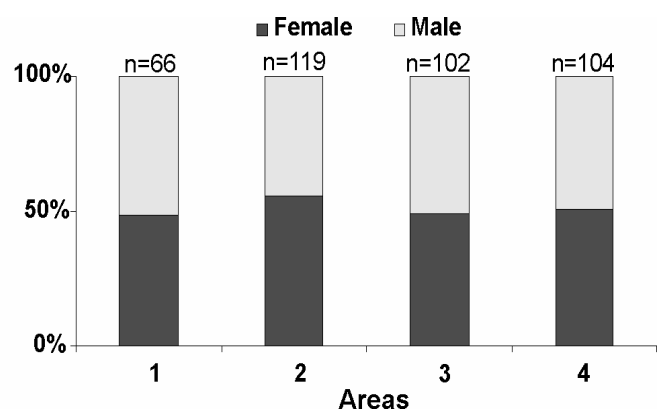

Fig. 4. Sex ratio of Isognomon bicolor on Costa (areas 1 and 2), Setibão (area 3) and Ubu (area 4). 
Density

The mean density of $I$. bicolor was significantly different among the studied areas, except for those of areas 2 and 4, that presented higher values $(\mathrm{F}=33,55 ; p<0.001)$ (Fig. 5).

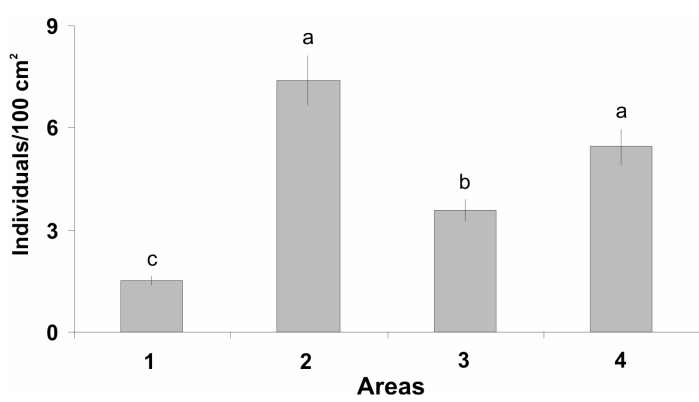

Fig. 5. Average density ( \pm standard error) of Isognomon bicolor at the sampling locations (areas 1 and 2: Costa, area 3: Setibão, area 4: Ubu). Homogeneous groups determined by the Tukey test are indicated with the same letters.

Results showed a negative correlation between the average density of I. bicolor and the number of crevices recorded in each area (Fig. 6).

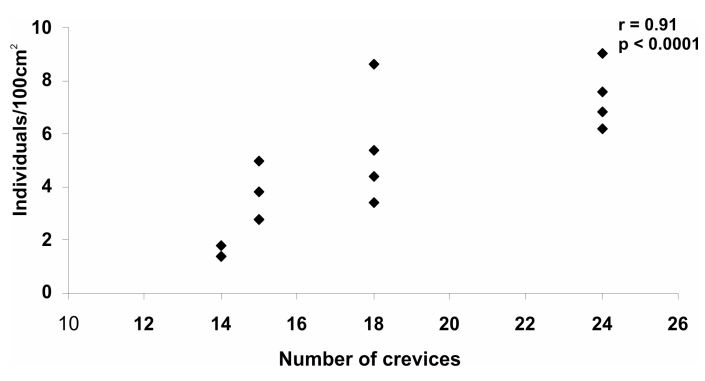

Fig. 6. Correlation between the mean density of Isognomon bicolor in each area and season and the number of crevices recorded on Costa (Areas 1 and 2), Setibão (Area 3) and Ubu (Area 4). The results of the Spearman test are presented in the figure $(\alpha=0.05 ; \mathrm{N}=16)$.

\section{Size-frequency Distribution}

A total of 974 individuals from 160 quadrants were collected and measured. Also, 17 empty shells were found within the quadrants. A greater number of $I$. bicolor was observed in areas with crevices ( $63 \%$ of the total sampled) than on flat surfaces.

Individuals were distributed in 11 size classes, according to the length of the shells, with intervals of $0.35 \mathrm{~cm}$. In general, the highest frequencies were found distributed in shell length intervals ranging from $1.07 \mathrm{~cm}$ to $2.5 \mathrm{~cm}$ (classes 3 to 6) (Fig. 7).

Comparing the flat and creviced surfaces in each area, individuals collected in the crevices presented a greater size range. Larger individuals (size classes between 7 and 11) were rarely found on flat surfaces (Fig. 7).

Means Values of Length, Height and Weight of I. bicolor

The estimated means for length, height and weight of I. bicolor were higher in the creviced areas than on flat surfaces (Fig. 8), with significant differences, according to the Bonferroni test $(p<$ $0.001)$.

For length, areas $1(1.94 \mathrm{~cm} \pm 0.05)( \pm$ standard error) and $2(2.03 \mathrm{~cm} \pm 0.03)$ showed the highest averages, differing from areas $3(1.70 \mathrm{~cm} \pm$ $0.03)$ and $4(1.62 \mathrm{~cm} \pm 0.02)$. Areas $1(1.31 \mathrm{~cm} \pm 0.03)$ and $2(1.37 \mathrm{~cm} \pm 0.01)$ also presented higher mean heights than areas $3(1.21 \mathrm{~cm} \pm 0.02)$ and $4(1.14 \mathrm{~cm} \pm$ $0.01)$. Mean weights also indicated that areas $1(1.24 \mathrm{~g}$ $\pm 0.08)$ and $2(1.29 \mathrm{~g} \pm 0.05)$ were significantly different from those of areas $3(0.75 \mathrm{~g} \pm 0.04)$ and 4 $(0.72 \mathrm{~g} \pm 0.03)$ (Table 1).

All the tested interactions between variables revealed significant differences in the average values of length, height and weight (Table 1).

\section{DisCUSSION}

The density of Isognomon bicolor on rocky shores was considered low in comparison with those of studies undertaken in Rio de Janeiro, whose authors reported densities of up to 445 individuals per $100 \mathrm{~cm}^{2}$ (FERNANDES et al., 2004). This fact, together with the absence of previous studies in the sampling areas, suggests that the invasion of this species has occurred recently in the Espírito Santo State. Despite the fact that is a recent invasion, I. bicolor occurred throughout the sampling areas along the studied period, indicating that populations are well established in the studied rocky shores.

Many studies in the intertidal region suggest that depressions or crevices represent microhabitats offering protection against desiccation, mechanical impact of waves, and predators (RAFFAELLI; HAWKINS, 1999; BARRETO, 1999; BLANCHARD; BOURGET, 1999; KOSTYLEV et al., 2005). Comparing the results of flat surfaces and crevices, the latter showed a greater number of individuals for all the areas and periods studied, indicating that in that environment, the settlement of these individuals is easier. Further, the individuals are more closely aggregated in the crevices, differently from the flat surfaces. Similarly, Moysés et al. (2007) noted that I. bicolor, in the early stages of succession, presents an aggregate distribution colonizing only depressions of the substrate. 


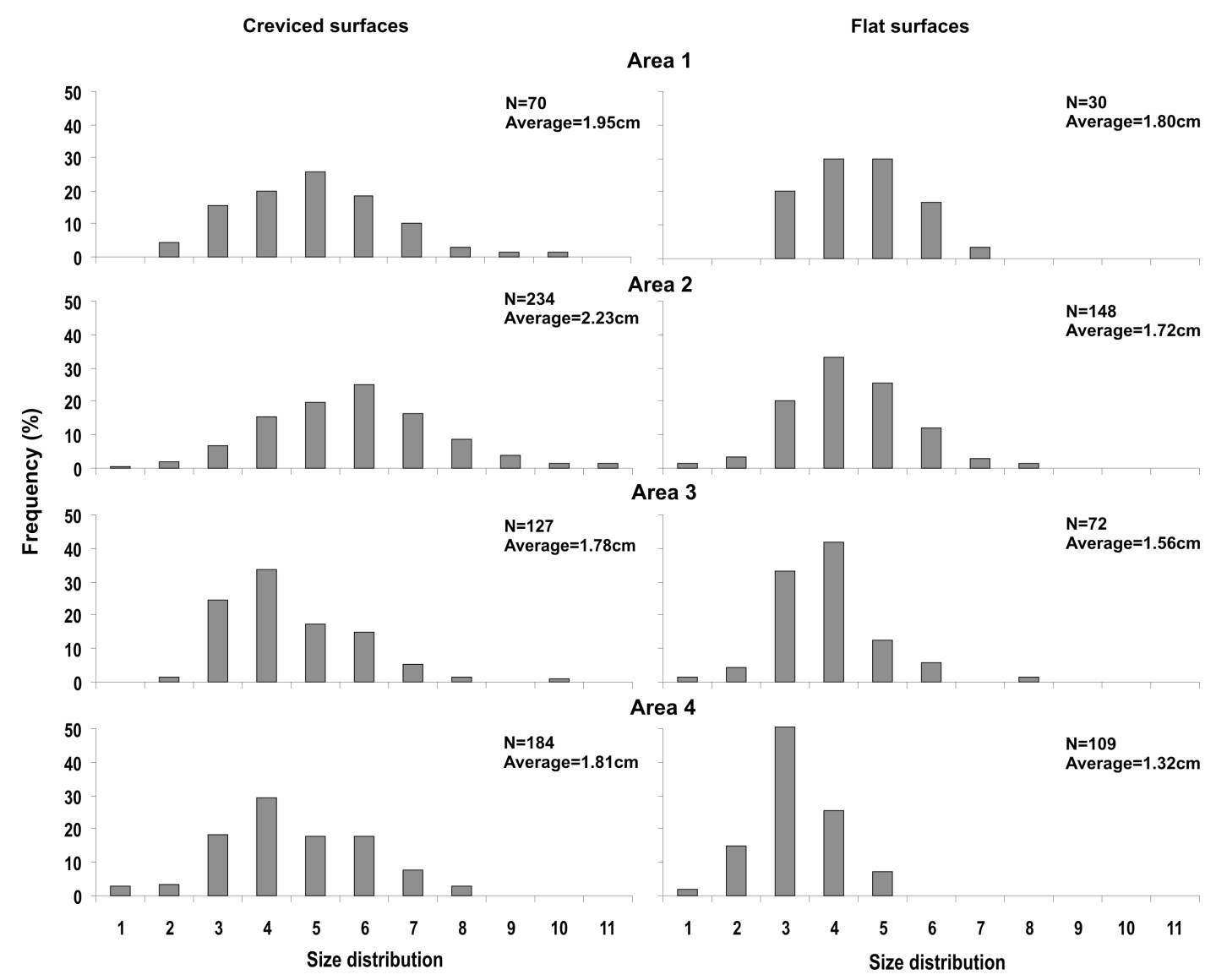

Fig. 7. Isognomon bicolor shell length size-frequency distribution on Costa (areas 1 and 2), Setibão (area 3) and Ubu (area 4) collected on flat surfaces (without depressions) and creviced surfaces, from August 2006 to May 2007 ( $\mathrm{N}=$ number of individuals measured).

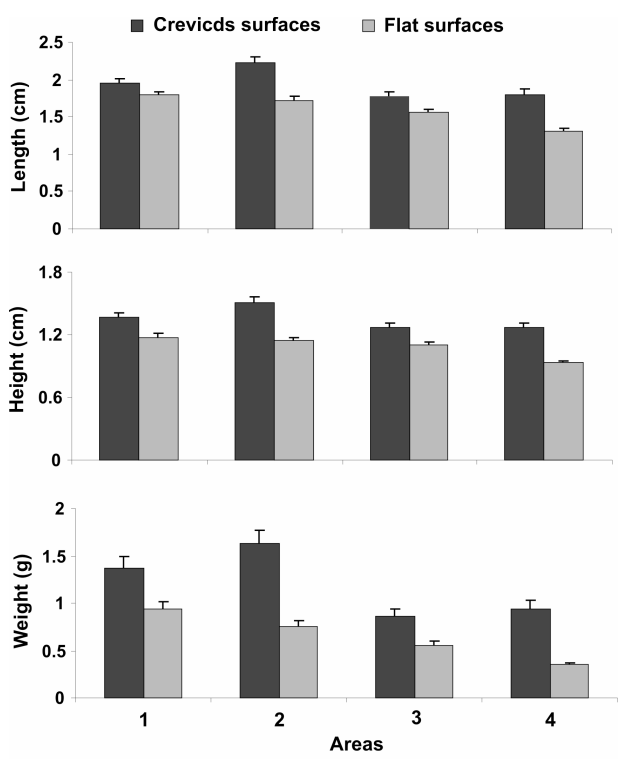

Fig. 8. Average values (+ standard error) of length, height and weight of Isognomon bicolor on Costa (areas 1 and 2), Setibão (area 3) and Ubu (area 4) and the type of surface where individuals were collected (flat or creviced). 
Table 1. Results of two-factor ANOVA between sampling areas (Costa, areas 1 and 2, Setibão, area 3 and Ubu, area 4), and types of surface sampled (flat and creviced), with variables of lengths, heights and weights of shells of Isognomon bicolor. The homogeneous groups determined by the Tukey test were ordered from the lowest to the highest average value. F: test value; P: probability associated with the test value; $\alpha=0.05$.

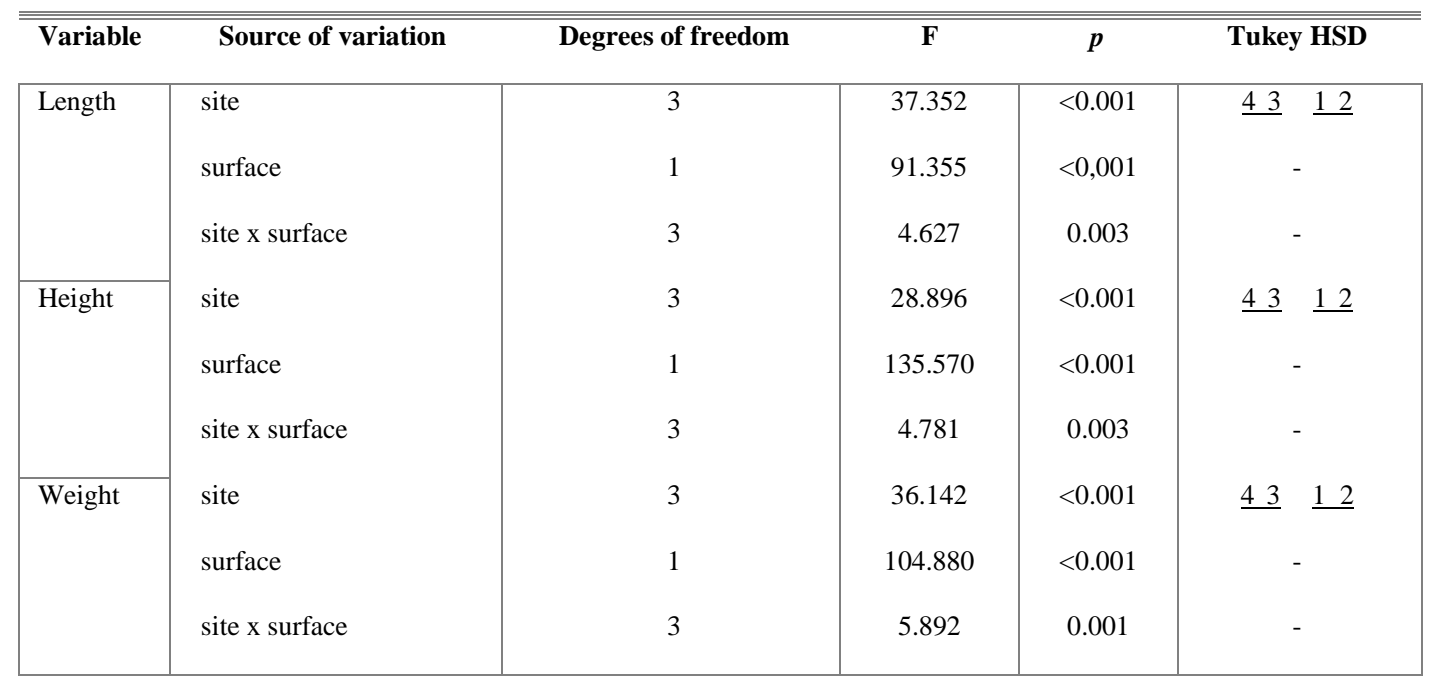

Densities were significantly different for sampling locations, with the greatest difference recorded between the two closest areas (areas 1 and 2). This difference can be explained by the greater number of crevices in area 2 and their dimensions. There is a positive correlation between the number of crevices and density, demonstrating that the establishment of individuals is easier in the crevices and, consequently, the resident population influences their colonization also in the smooth adjacent areas. The filter feeders are extremely selective of substrates to which they will attach (LITTLE; KITCHING, 1996), thus, many studies indicate that local environmental characteristics and the resident population can have a strong effect on larval recruitment (OSMAN; WHITLATCH, 1995).

According to Skinner and Coutinho (2005), the settlement of the barnacle larvae Tetraclita stalactifera is influenced by substrate heterogeneity, as the greater the roughness, the larger the settlement, due to changes in the water flow and increased larval retention. Moreover, it is likely that I. bicolor selects the crevices in which to settle or otherwise, that the crevices are a refuge from predators and more extreme physical factors, resulting in higher survival of recruits in these microhabitats. Future experimental studies may help to clarify these points.

In crevices, the organisms were significantly larger and heavier than those collected on smooth surfaces. Blanchard and Bourget (1999) recorded higher values of intertidal community biomass in crevices, thus corroborating the findings of this study. According to Murray et al. (2006), topographic heterogeneity causes turbulence that can dissipate the wave energy providing sheltered microhabitats, and possibly increasing food availability. Depressions are, therefore, less stressful environments for organisms to feed, since they spend more time submerged in comparison with those on smooth surfaces. This also helps to explain the larger sizes and weights registered.

The highest size-frequency of organisms was found in intermediate size classes, and the smaller ones in lower and higher classes. This type of population structure was also found by Fernandes et al. (2004) for this species. In other studies with bivalves, Alvarado and Castilla (1996) found a bimodal size distribution with high frequency of recently established individuals and adults.

The differences in the populations of $I$. bicolor found could be due to substrate heterogeneity (quantity of crevices), this being an important factor in explaining variability on a small scale, corroborating the results of Araujo et al. (2005) that suggest horizontal variability of intertidal communities on a scale of a few meters, related to habitat heterogeneity.

\section{ACKNOWLEDGEMENTS}

We would like to thank Dr. Andrea de Oliveira Ribeiro Junqueira, Dr. Jean-Christophe Joyeux and MSc. Mércia Barcellos da Costa for their important contributions to this work, as well as our colleagues of the Malacology Laboratory (UFES) for their assistance in the various stages of this study.

\section{REFERENCES}

ALBINO, J.; PAIVA D.S.; MACHADO G.M. Geomorfologia, tipologia, vulnerabilidade erosiva e ocupação urbana das praias do litoral do Espírito Santo, Brasil. Geografares, v. 2, n. 2, p. 63-69, 2001. 
ALVARADO, J.L.; CASTILLA, J.C. Tridimensional matrices of mussels Perumytilus purpuratus on intertidal platforms with varying wave forces in central Chile. Mar. Ecol. Prog. Ser., v. 133, p.135-141, 1996.

AMARAL, A.C.; JABLONSK, S. Conservation of Marine and Coastal Biodiversity in Brazil. Conserv. Mar. Coast. Biodivers., v. 19, n. 3, p.625-631, 2005.

ARAÚJO, R.; BÁRBARA, I.; SOUSA-PINTO, I.; QUINTINO V. Spatial variability of intertidal rocky shore assemblages in the northwest coast of Portugal. Est. Coast. Shelf. Sci., v. 64, n. 4, p. 658-670, 2005.

ARCHAMBAULT, P.; BOURGET, E. Scales of coastal heterogeneity and benthic intertidal species richness, diversity and abundance. Mar. Ecol. Prog. Ser., v. 136, p. 111-121, 1996.

BARRETO, C.C. Heterogeneidade espacial do habitat e diversidade específica: implicações ecológicas e métodos de mensuração. Oecol. Brasiliensis, v. 7, p. 121-153, 1999.

BLANCHARD, D.; BOURGET, E. Scales of coastal heterogeneity: influence on intertidal community structure. Mar. Ecol. Prog. Ser., v. 179, p. 163-173, 1999.

BENEDETTI-CECCHI, L.; CINELLI, F. Spatial distribution of algae and invertebrates in the rocky intertidal zone of the Strait of Magellan: are patterns general? Pol. Biol., v. 18, n. 5, p. 337-343, 1997.

CARLTON, J.T. Introduced marine and estuarine mollusks of North America: an end-of-the-20th-century perspective. J. Shellfish Res., v. 11, n. 2, p. 489-505, 1992.

CROWE, T.P.; THOMPSON. R.C.; BRAY, S.; HAWKINS, S.J. Impacts of anthropogenic stress on rocky intertidal communities. J. Aquatic. Ecosyst. Stress Recovery, v. 7, n. 4, p. 273-297, 2000.

DOMANESCHI, O.; MARTINS C.M. Isognomon bicolor (C.B.Adams) (Bivalvia, Isognomonidae): primeiro registro para o Brasil, redescrição da espécies e considerações sobre a ocorrência e distribuição de Isognomon na costa brasileira. Rev. Bras. Zool., v. 16, n. 2, p. 611-627, 2002.

FERNANDES, F.C.; RAPAGNÃ L.C.; BUENO, G.B. Estudo da população do bivalve exótico Isognomon bicolor (C.B. Adams, 1845) (Bivalvia, Isognomonidae) na Ponta da Fortaleza em Arraial do Cabo - RJ. In: SILVA, J.S.V.; SOUZA, R.C.C.L. (Ed). Água de Lastro e Bioinvasão. Rio de Janeiro: Interciência, 2004, p. 133141.

GUICHARD, F.; BOURGET, E.; ROBERT, J. Scaling the influence of topographic heterogeneity on intertidal benthic communities: alternate trajectories mediated by hydrodynamics and shading. Mar. Ecol. Prog. Ser., v. 217, p. 27-41, 2001.

KADO, R. Invasion of Japanese shores by the NE Pacific barnacle Balanus gleula and its ecological and biogeographical impact. Mar. Ecol. Prog. Ser., v. 249, p. 199-206, 2003.

KOSTYLEV, V.E.; ERLESSON, J.; MING, M.Y.; WILLIAMS, G.A. The relative importance of habitat complexity and surface area in assessing biodiversity: Fractal application on rocky shores. Ecol. Complex., v. 2, n. 3, p. 272-286, 2005.
LITTLE, C.; KITCHING, J. A. The biology of rocky shores. New York: Oxford University Press, 1996, p. 252.

MARTIN, L; SUGUIO, K.; FLEXOR, J.M.; ARCANJO, J.D. Coastal quaternary formations of the southern part of the State of Espírito Santo (Brazil). An. Acad. Bras. Cienc., v. 68 , n. 3, p. 389-404, 1996.

MASSAD, E; MENEZES, R.X.; SILVEIRA, P.S.P.; ORTEGA, N.R.S. Métodos quantitativos em medicina. São Paulo: Manole, 2004, p. 561.

MENCONI, M.; BENEDETTI-CECCHI, L.; CINELLI, F. Spatial and temporal variability in the distribution of algae and invertebrates on rocky shores in the northwest Mediterranean. J. Exp. Mar. Biol. Ecol., v. 233, n. 1, p. 1-23, 1999.

MOYSÉS, D.N.; JUNQUEIRA, A.O.R.; LAVRADO, H.P.; SILVA, S.H.G. Method for monitoring intertidal communities in a steep rocky shore: a combination of digital image technology and field operational strategy. Braz. J. Ocean., v. 55, n. 1, p. 19-27, 2007.

MURRAY, S.N.; AMBROSE, R.F.; DETHIER, M.N. Monitoring rocky shores. London: University Press, 2006, 248 p.

OSMAN, R.W.; WHITLATCH, R.W. The influence of resident adults on recruitment: a comparison to settlement. J. Exp. Mar. Biol. Ecol., v. 190, n. 2, p. 169198, 1995.

RAFFAELLI, D.; HAWKINS, S. Intertidal Ecology. London: Kluwer Academic Publishers, 1999, 356 p.

RUIZ, G.M.; CARLTON, J.T.; GROSHOLZ, E.D.; HINES, A.H. Global invasions of marine and estuarine habitats by non-indigenous species: Mechanisms, extent, and consequences. Am. Zool., v. 37, n. 2, p. 621-632, 1997.

SKINNER, L.F.; COUTINHO, R. Effect of microhabitat distribution and substrate roughness on barnacle Tetraclita stalactifera (Lamarck, 1818) settlement. Braz. Arch. Biol. Technol., v. 48, n. 1, p. 109-113, 2005.

UNDERWOOD, A.J. Landing on one's foot: small-scale topographic features of habitats and the dispersion of juvenile intertidal gastropods. Mar. Ecol. Prog. Ser., v. 268, p. 173-182, 2004.

ZAR, J. H. Biostatistical Analysis. New Jersey: Prentice Hall, 1996, 662 p.

XAVIER, E.A.; GAMA, B.A.P.; PORTO, T.F.; ANTUNEZ, B.L.; PEREIRA, R.C. Effects of disturbance area on fouling communities from a Tropical environment: Guanabara Bay, Rio de Janeiro, Brazil. Braz. J. Oceanogr., v. 56 